(Received June 24, 1981)

\title{
STRUCTURAL CHARACTERIZATION OF HIGHLY REDRAWN ISOTACTIC POLYPROPYLENE FILMS*
}

\author{
By Yuzo Yamamoto, Mitsuto Dewasawa and Shigetake Kinoshita \\ (Faculty of Technology, Gunma University, Kiryu-City, Japan)
}

\begin{abstract}
The preoriented isotactic polypropylene (iPP) film, which was prepared by drawing and annealing, was redrawn at the angles of $\alpha\left(\alpha=0,30,45\right.$ and $\left.60^{\circ}\right)$ to the preoriented direction (named the first draw direction FDD). By high redrawing, the preoriented iPP films were highly reoriented to the redrawing direction (named the second draw direction SDD). The films had the high crystal and amorphous orientation factors; such as $f_{\mathrm{c}}=0.992$ and $f_{\mathrm{am}}=0.714$. The dependence of $T_{\mathrm{m}}$ on DSC scan speed was examined and it was found that the degree of superheating increased with $f_{\mathrm{am}}$. A history of the preorientation remained in the highly redrawn films and it appeared during thermal shrinkage at higher temperatures.
\end{abstract}

\section{INTRODUCTION}

In the previous papers ${ }^{1,2)}$, we studied the deformation behavior of the preoriented isotactic polypropylene (iPP) films by the redrawing performed at the angles of $\alpha(\alpha=0,30,45,60$, and $\left.90^{\circ}\right)$ to the preoriented direction (named the first draw direction, FDD). Further, we studied the structural changes of the highly reoriented films by thermal shrinkage ${ }^{3)}$. and found that the crystal $c$-axis which had reoriented highly to the deformation direction (named the second draw direction, SDD) rotated to the FDD by thermal shrinkage at higher temperatures. That is, the history of the preorientation remains even in the highly redrawn films and it appears during thermal shrinkage. The crystal reorientation may be mainly caused by the relaxation of the strained amorphous chains and the partial melting of crystallites. On the other hand, it is expected that the development of the strained amorphous chains leads to the increment of crystal and amorphous orientations in highly redrawing. In addition, it is an interesting problem whether the crystals having higher orientations to the SDD rotate or not to the FDD by thermal shrinkage.

The high values of crystal orientation factor $f_{\mathrm{c}}$ and amorphous orientation factor $f_{\mathrm{am}}$ have been

* Studies on the redrawing of drawn-annealed films. Part IV. reported in the literatures: $0.95^{4)}, 0.996^{5)}$, $0.9968^{6)}, 0.994^{7)}$, and $0.997^{8)}$ for $f_{\mathrm{c}}$ and $0.7163^{9}$, $\left.0.72^{4}\right), 0.75^{6)}$, and $0.657^{8)}$ for $f_{a m}$. However, there are few reports on the films or fibers which have high values of $f_{\mathrm{c}}$ and $f_{\mathrm{am}}$ concurrently. For example, Desper ${ }^{6)}$ obtained the values; $f_{\mathrm{c}}=0.9968$, $f_{\mathrm{am}}=0.64$ and $f_{\mathrm{c}}=0.9963, f_{\mathrm{am}}=0.75$ for the thin highly drawn polypropylene films.

We obtained the films which had high values of crystal and amorphous orientation by highly redrawing of the preoriented iPP films. In the present paper, the structural characterization of the highly redrawn iPP films was investigated by means of $\mathrm{x}$-ray diffraction methods and DSC measurements.

\section{EXPERIMENTAL}

\subsection{Sample preparation}

The used material was a iPP film (supplied Chisso Co. Ltd., $M_{\eta}=30 \times 10^{4}$ ). The sample was moulded into film about $400 \mu \mathrm{m}$ in the thickness at $220^{\circ} \mathrm{C}$ for $10 \mathrm{~min}$ and subsequently quenched in ice-water. The film was drawn at $80^{\circ} \mathrm{C}$ with necking and annealed at $T_{\mathrm{a}}=140^{\circ} \mathrm{C}$ for $30 \mathrm{~min}$. in an air bath, keeping the film ends free. Thus obtained film was used as an original sample (A film named in the previous paper ${ }^{1)}$ ) and the $\mathrm{x}$-ray diffraction patterns of it are shown in Fig. 1. The long period estimated from small angle $\mathrm{x}$-ray scattering (SAXS) was $244 \mathrm{~A}$. The original film was redrawn to the draw ratios as high as possible 


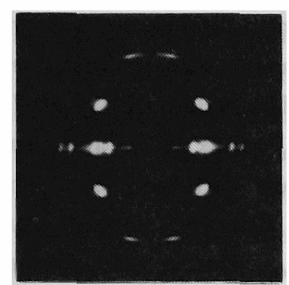

thru

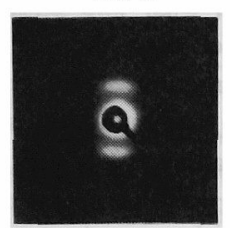

Draw direction

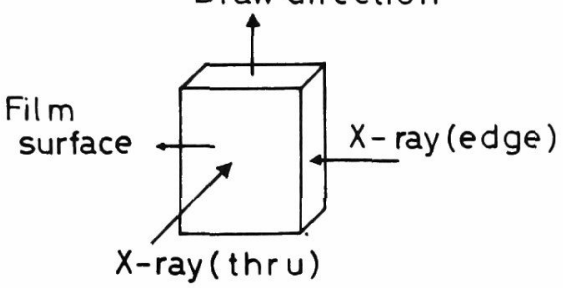

Fig. 1 Wide-angle $x$-ray diffraction (WAXD) and small-angle $x$-ray scattering (SAXS) patterns of the original film. The directions of incident $\mathrm{x}$-ray beam are normal to the film surface (thru view) and parallel to it (edge view).

at $110^{\circ} \mathrm{C}$ in the direction of angles $\alpha(\alpha=30,45$ and $\left.60^{\circ}\right)$ to the FDD. The obtained draw ratios $\lambda$ were 4.2, 5.0, and 6.0 for $\alpha=30,45$, and $60^{\circ}$, respectively. The sample film drawn to $\lambda=2.5$ at $\alpha=0^{\circ}$ was also prepared.

As in the previous paper ${ }^{1)}$, the films redrawn to $\lambda$ at $\alpha$ were denoted by $\mathrm{A}_{\alpha, \lambda}$.

\section{$2.2 \mathrm{X}$-ray diffraction patterns}

Rota flex RU-3 instrument (Rigaku Denki Co.) was employed. The radiation used was $\mathrm{Ni}$ filtered $\mathrm{CuK}_{\alpha}$ of wavelength $1.542 \AA$. X-ray diffraction photographs were obtained using a point collimation Rigaku Denki small-angle camera and a flat wide-angle camera.

The diffraction intensity of the (hkl) crystal plane was recorded by a scintilation counter.

\subsection{Crystallite sizes}

Crystallite sizes were estimated from wide-angle $\mathrm{x}$-ray diffraction (WAXD) patterns using Scherrer's equation

$$
D_{\mathrm{hk} 1}=K \lambda / \beta \cos \theta_{\mathrm{hk} 1}
$$

where $D_{\mathrm{hkl}}$ is the average dimension of the crystallites normal to the diffraction planes (hkl); $\lambda$ is the wavelength $(1.542 \AA) ; \beta$ is the integral breadth of the reflection in radians; $\theta$ is the Bragg angle; and $K$ is a shape factor depending on the method of determining $\beta$ and is taken as 1.05 for integral breadth of diffraction. The observed diffraction breadths $(B)$ were corrected for instrumental broadening by Warren's method

$$
\beta^{2}=B^{2}-b^{2}
$$

where $b$ is the integral breadth of a standard silicon powder.

\subsection{Orientation}

The end view of the WAXD patterns (incident $\mathrm{x}$-ray beam is parallel to the SDD) of the highly redrawn films show nearly uniform rings and the refractive index of the direction of the film thickness is nearly equal to that of the direction of perpendicular (parallel to the film surface) to the SDD. Accordingly, it is considered that these films have an orientation of cylindrical symmetry to the SDD.

The crystal orientation factors $f_{c}, f_{b}$ and $f_{a}$ were estimated from the azimuthal intensity distributions of the (110) and (040) reflections using Wilchinsky's method. Here, $f_{c}, f_{b}$ and $f_{a^{\prime}}$ are represent the orientation factors of the crystal $c$, $b$ - and $a^{\prime}$-axis, respectively.

Amorphous orientation factor $f_{\mathrm{am}}$ was estimated from the birefringence and $x$-ray crystal orientation data according to the relation

$$
\Delta n=f_{\mathrm{am}}\left(1-\chi_{\mathrm{v}}\right) \Delta n_{\mathrm{a}}^{\circ}+f_{\mathrm{c}} \chi_{\mathrm{v}} \Delta n_{\mathrm{c}}^{\circ}
$$

where $\Delta n$ is the birefringence obtained from an Abbe refractometer ${ }^{10)}$ and the value is corrected to the value at the density of $0.900 \mathrm{~g} / \mathrm{cm}^{3}$ as Okajima et al. already reported ${ }^{11)} ; \chi_{\mathrm{v}}$ is the degree of crystallinity in volume fraction estimated from the density. Densities were determined by refractive index using Okajima's equation ${ }^{12)} ; \Delta n_{\mathrm{a}}^{\circ}$ and $\Delta n_{\mathrm{c}}^{\circ}$ are the intrinsic birefringence of the amorphous and crystalline regions, respectively and $\Delta n_{\mathrm{a}}^{\circ}=38.5 \times 10^{-3}$ and $\Delta n_{\mathrm{c}}^{\circ}=41.5 \times 10^{-313)}$ are used here.

\subsection{DSC measurements}

Melting points $T_{\mathrm{m}}$ were determined using a Perkin-Elmer DSC-2. Standard correction was made for change in apparent melting points. As a 
standard, indium $\left(T_{\mathrm{m}}=156.4^{\circ} \mathrm{C}\right)$ was used. The highest temperatures at the maxima of the endotherms were taken as the $T_{\mathrm{m}}$ of samples. Heating rates were varied in the range of $2.5^{\circ} \mathrm{C} / \mathrm{min}$ to $80^{\circ} \mathrm{C} / \mathrm{min}$.

\subsection{Thermal shrinkage}

Thermal shrinkage was carried out in an air bath at $160^{\circ} \mathrm{C}$ for $10 \mathrm{~min}$ and the degree of thermal shrinkage $S$ was calculated according to

$$
S=\frac{l_{0}-l}{l_{0}} \times 100
$$

where $l_{0}$ and $l$ are the length of the sample before and after thermal shrinkage, respectively.

\section{RESULTS AND DISCUSSION}

\subsection{Morphology of the highly redrawn films}

Typical WAXD and SAXS patterns of the highly redrawn films are shown in Fig. 2. The sharpness of the WAXD spots indicates a very high degree of crystal orientation. On the other hand, the SAXS patterns do not show any long period spacing but only give a central diffuse scattering (thru view) or a streak (edge view). That is, by highly redrawing, the original lamellar structure seems to be destroyed and the crystallites highly reorient around the SDD.

The orientation factors, the crystallite sizes, and the crystallinity of the original and the highly redrawn films are summarized in Table 1. The orientation factor of the crystal $c$-axis $f_{c}$ is very high for the redrawn films. The amorphous orientation factor $f_{\mathrm{am}}$ is also high, especially for $\mathrm{A}_{45,5.0}$ and $\mathrm{A}_{60,6.0}$. For $\mathrm{A}_{60,6.0}$, the values of $f_{c}$ and $f_{\mathrm{am}}$ are 0.991 and 0.714 , respectively. $f_{c}=0.991$ means approximately perfect orientation of the crystal $c$-axis to the SDD. The value $f_{\text {am }}=0.714$ is comparable to the very high value $f_{\mathrm{am}}=0.75$ reported by Desper ${ }^{6}$ ) for thin, highly drawn polypropylene film that prepared by a continuous process involving drawing between rollers in a radiant heat oven near the melting point. (The value of $f_{\mathrm{am}}=0.75$ was obtained using a $\Delta n_{\mathrm{a}}^{\circ}=60 \times 10^{-3}$ and $\Delta n_{\mathrm{c}}^{\circ}$ $\left.=29.1 \times 10^{-3} 14\right) \quad$ These are different from the values used in our study. But, by changing $\Delta n_{\mathrm{a}}^{\circ}$ and $\Delta n_{\mathrm{c}}^{\circ}$, the value of $f_{\mathrm{am}}$ almost remains unchanged.)

The crystallite sizes $D_{110}, D_{040}$ and $D_{130}$ for the redrawn films are smaller than those of the original film in the each directions. But the $\alpha$ dependency of the crystallite size reduction is not clear. The degree of crystallinity $\chi_{\mathrm{v}}$, also, decreases by redrawing. The crystallites seems to be destroyed by redrawing and this may lead to the reduction of crystallinity.

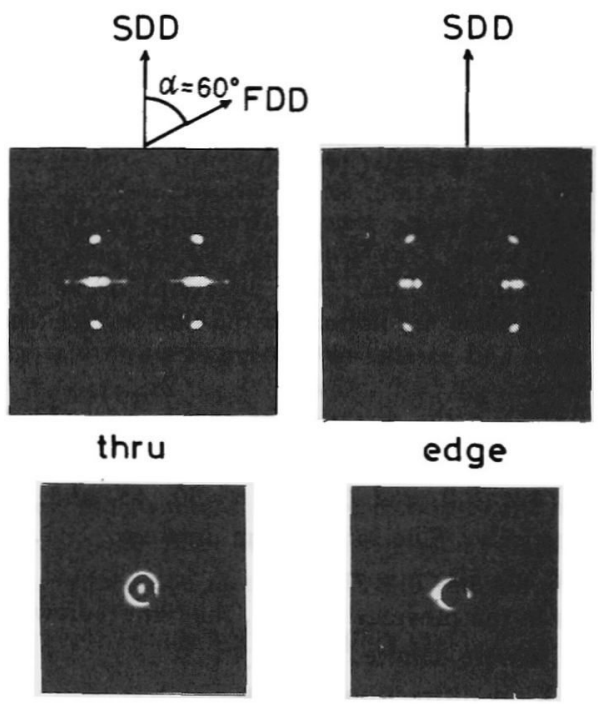

Fig. 2 WAXD and SAXS patterns of $A_{60,6.0}$ film. SDD: second draw direction, FDD: first draw direction, $\alpha$ : redrawing angle.

Table 1 Characteristics of the sample films.

\begin{tabular}{l|cccc|ccc|c}
\hline & \multicolumn{4}{|c|}{ Orientation Factor } & \multicolumn{3}{c|}{ Crystallite Size $(\AA)$} & Crystallinity \\
& $f_{c}$ & $f_{b}$ & $f_{a^{\prime}}$ & $f_{\mathrm{am}}$ & $\mathrm{D}_{110}$ & $\mathrm{D}_{040}$ & $\mathrm{D}_{130}$ & $\chi_{v}(\%)$ \\
\hline Original & 0.968 & -0.482 & -0.486 & 0.337 & 94 & 91 & 87 & 50.8 \\
$\mathrm{~A}_{\mathbf{0 , 2 5}}$ & 0.992 & -0.496 & -0.496 & 0.428 & 86 & 84 & 78 & 46.7 \\
$\mathrm{~A}_{\mathbf{3 0 , 4 . 2}}$ & 0.993 & -0.497 & -0.496 & 0.574 & 87 & 84 & 80 & 46.1 \\
$\mathrm{~A}_{\mathbf{4 5}, \mathbf{5 . 0}}$ & 0.992 & -0.496 & -0.496 & 0.714 & 80 & 80 & 78 & 46.8 \\
$\mathrm{~A}_{60,6.0}$ & 0.991 & -0.497 & -0.494 & 0.714 & 84 & 79 & 80 & 45.4 \\
\hline
\end{tabular}




\subsection{Differential scanning calorimetry}

Fig. 3 shows the DSC thermograms of the original and the redrawn films. The melting endotherm of the original film has a double melting peaks in a narrow temperature range. As the original film is annealed at $140^{\circ} \mathrm{C}$, it seems that the lower temperature melting peak corresponds to the melting of crystals developed during annealing.

For $\alpha=0^{\circ}\left(\mathrm{A}_{0,2.5}\right)$, the melting curve is similar to that of the original film but the low temperature peak sharpens and shifts to a higher temperature. For $\alpha=30\left(A_{30,4.2}\right), 45\left(A_{45,5.0}\right)$ and $60^{\circ}\left(A_{60,6.0}\right)$, they do not show the double melting peaks which appear on that of the original or $A_{0,2.5}$ films, but show irregular profiles. By redrawing, the melting temperature, generally, shifts to higher temperatures and the width of the endotherm broadens.

As in Table 1, the crystallite sizes of the redrawn films are smaller than those of the original film, however, the melting temperature becomes higher by redrawing. In general, the melting temperature increases with an increase in crystal size and/or crystal perfection. If both of them do not increase so much with the highly redrawing, the shifts of $T_{\mathrm{m}}$ to higher temperatures is due to a superheating effect by the entropy loss imposed by chain constraints given by redrawing in the amorphous

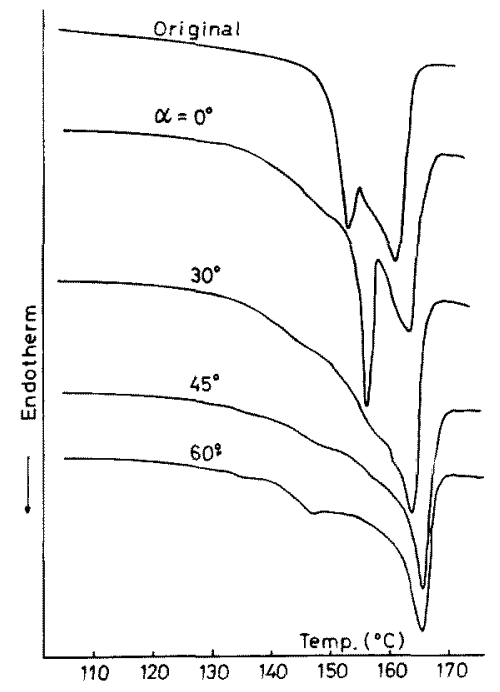

Fig. 3 DSC thermograms of the original and redrawn films. $\quad \alpha=0^{\circ} \mathrm{A}_{0,2.5} ; \quad \alpha=30^{\circ} \mathrm{A}_{30,4.2}$; $\alpha=45^{\circ} \mathrm{A}_{45,5.0} ; \alpha=60^{\circ} \mathrm{A}_{60,6.0}$ phase. Taking into account the reduction of crystallinity and width of crystallites, the speculation may be reasonable. Then, to investigate the superheating effect, the melting temperature was measured at different heating rates for the original, the redrawn and a melt-quenched films.

Fig. 4 shows the dependence of the melting temperature, $T_{\mathrm{m}}$ on DSC scan speeds. $T_{\mathrm{m}}$ of the highly redrawn films is higher than that of the original and a melt-quenched films at any heating rate. For all sample films, $T_{\mathrm{m}}$ decreases with the heating rate and has a minimum at the heating rate of 10 to $40^{\circ} \mathrm{C} / \mathrm{min}$. But for the melt-quenched film, $T_{\mathrm{m}}$ remains unchanged at above the heating rate of $20^{\circ} \mathrm{C} / \mathrm{min}$. The heating rate at the minimum of $T_{\mathrm{m}}$ shifts to $10^{\circ} \mathrm{C} / \mathrm{min}$ for $\alpha=45$ and $60^{\circ}$ from $40^{\circ} \mathrm{C} / \mathrm{min}$ for the original film. That is, the minimum shifts to lower heating rates with increasing

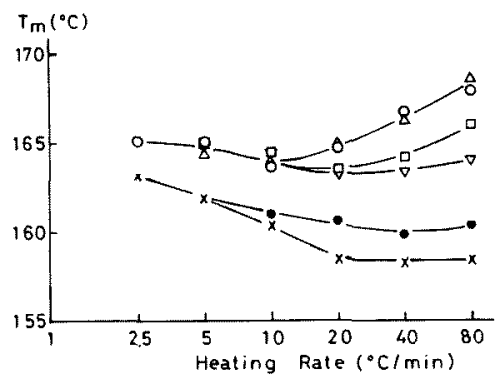

Fig. 4 Plot of the melting temperature of the original, redrawn and melt quenched films as a function of the heating rate. (-) original;
$(\nabla) A_{0,2.5}$
(ㅁ) $\mathrm{A}_{30,4.2}$
$(\triangle) A_{45,5.0}$
(O) $A_{60,6.0}$
$(X)$ melt quenched film

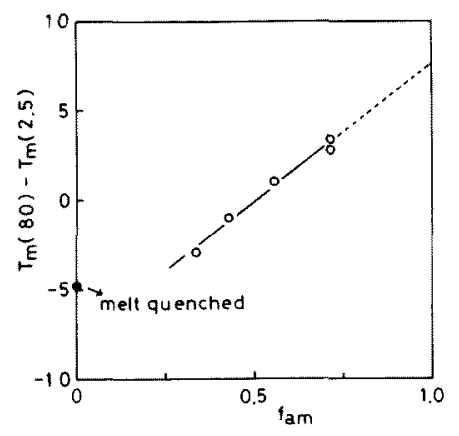

Fig. 5 Plot of the difference between $T_{m}$ at the heating rate of $80^{\circ} \mathrm{C} / \mathrm{min}$ and that of $2.5^{\circ} \mathrm{C} / \mathrm{min}$ as a function of the amorphous orientation factor $f_{\mathrm{am}}$. 
the amorphous orientation factor $f_{\mathrm{am}}$. On the other hand, the degree of superheating depends on the redrawing angle $\alpha$ of sample films. This result, also corresponds to the values of the amorphous orientation factor $f_{\mathrm{am}}$. That is, the superheating effect increases with $f_{\mathrm{am}}$. In Fig. 5 , the difference between $T_{\mathrm{m}}$ at the heating rate of $80^{\circ} \mathrm{C} / \mathrm{min}$ and that of $2.5^{\circ} \mathrm{C} / \mathrm{min}$ is plotted against the $f_{\mathrm{am}}$. As expected, the difference increases with $f_{\mathrm{am}}$. The difference of $T_{\mathrm{m}}$ at $f_{\mathrm{am}}=1.0$, which is estimated by the extrapolation of the straight line, is $7.6^{\circ} \mathrm{C}$ and then $T_{\mathrm{m}}$ becomes $172.7^{\circ} \mathrm{C}$ at the heating rate of $80^{\circ} \mathrm{C} / \mathrm{min}$. For the melt-quenched film, the crystallite sizes and the crystal perfection may be appreciably different from those of the other sample films. Consequently, it seems that the data for the melt-quenched film is not on the straight line. Thus, the observed superheating effect can be understood in terms of the increasing constraints on the amorphous regions by the redrawing.

Wunderlich ${ }^{15)}$ has shown that superheating depends on the width of crystals as well as on the crystal thickness and molecular weight. On the other hand, Zachmann has shown that conditions for superheating can occur either when all the chain ends are concentrated on the crystal surface (extended chain crystals) or when a stack of conventional crystals is connected by strained amorphous material ${ }^{16,17)}$. And Hellumuth and Wunderlich has shown that the melting temperature of extended-chain crystals increases, whereas metastable folded-chain crystals display a lowering of the melting temperature as the heating rate is increased ${ }^{18}$ ). Then, if a number of extended-chain crystals are produced by highly redrawing, $T_{m}$ may increase with heating rate. But, as seen in Fig. 4 , as the decrease of $T_{\mathrm{m}}$ is seen for all sample films, the existence of a number of extended-chain crystals is not supported experimentally even for the highly redrawn films. Hence, it is presumed that the minimum of $T_{\mathbf{m}}$, as seen in Fig. 4 , appears by the coupling of the two effects: the one is the increase of $T_{\mathrm{m}}$ by strained amorphous chains and the other is the decrease of $T_{\mathrm{m}}$ caused by foldedchain crystals accompanied by the increase of the heating rate. As $f_{\mathrm{am}}$ becomes higher values, the former effect appears preferentially and the heating rate at the minimum of $T_{m}$ shifts to slower heating rates. On the contrary, the latter effect appears preferentially in such a case of the original film or the melt-quenched film and superheating is scarcely shown.

\subsection{Structural change by thermal shrinkage}

Fig. 6 shows the typical WAXD and SAXS patterns of one of the films. The WAXD pattern of the highly redrawn films rotates back towards the first draw direction, FDD, even in the case of the film having a high degree of crystal and amorphous orientation, by thermal shrinkage of the sample film at $T_{\mathrm{s}}=160^{\circ} \mathrm{C}$ in a similar manner as described in the previous paper ${ }^{3)}$. The SAXS pattern shows a diffuse two-point reflection on the diagonal and this means that the lamellar structure stacked to the direction between the FDD and the SDD appears. By thermal shrinkage, the crystal $c$-axis tilts about $25^{\circ}$ to the SDD for the samples of $A_{30,4.2}, A_{45,5.0}$ and $A_{60,6.0}$ and then the lamellar normal, also, tilts about $25^{\circ}$ to the SDD. This fact shows that the crystal $c$-axis is parallel to the lamellar normal. That is, by thermal shrinkage, the strain energy stored by highly redrawing is relaxed and the rotation of crystals accompanying the chain slips along the chain axis may occur.
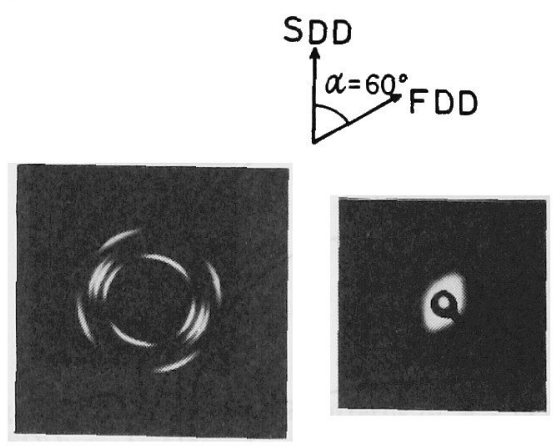

Fig. 6 WAXD and SAXS patterns of $A_{60,6.0}$ film shrunken at $160^{\circ} \mathrm{C}$ for $10 \mathrm{~min}$.

Thermal shrinkage is about $75 \%$ for the redrawn films and this value is comparable to the values obtained for the samples redrawn to $\lambda=4.0$ in the previous paper ${ }^{3)}$.

\section{CONCLUSION}

The preoriented isotactic polypropylene (iPP) film was redrawn at the angles of $\alpha(\alpha=0,30,45$ and $60^{\circ}$ ) to the preoriented direction. By high 
redrawing, the preoriented iPP films were highly reoriented to the redrawing direction, SDD and the redrawn films had the high crystal and amorphous orientation factors; such as $f_{\mathrm{c}}=0.992$ and $f_{\mathrm{am}}=0.714$.

The dependence of $T_{\mathrm{m}}$ on DSC scan speed was examined and it was found that the degree of superheating increased with $f_{\mathrm{am}}$. The plot of the difference between $T_{\mathrm{m}}$ at the heating rate of $80^{\circ} \mathrm{C} /$ min and that of $2.5^{\circ} \mathrm{C} / \mathrm{min}$ against $f_{\mathrm{am}}$ was linear.

A history of the preorientation remained in the highly redrawn films and it appeared during thermal shrinkage at higher temperatures: the crystal $c$-axis approached to the lamellar normal.

\section{REFERENCES}

1) Y. Yamamoto, S. Morishita, and S. Kinoshita, Sen-i Gakkaishi, 35, T-181 (1979)

2) Y. Yamamoto, S. Morishita, and S. Kinoshita, Sen-i Gakkaishi, 36, T-282 (1980)

3) Y. Yamamoto, S. Morishita, and S. Kinoshita, submitted to Sen-i Gakkaishi

4) R. J. Samuels, J. Macromol. Sci., B4, 701 (1970)

5) C. R. Desper, J. H. Southern, R. D. Ulrich, and R. S. Poter, J. Appl. Phys., 41, 4284 (1970)
6) C. R. Desper, J. Macromol. Sci., B7, 105 (1973)

7) W. T. Mead, C. R. Desper, and R. S. Poter, J. Polym. Sci., Polym. Phys. Ed, 17, 859 (1979)

8) W. Wu, P. G. Simpson and W. B. Black, J. Polym. Sci., Polym. Phys. Ed., 18, $751(1980)$

9) R. J. Samuels, J. Polym. Sci. Polym. Phys. $E d_{0}, 13,1417$ (1975)

10) S. Okajima and Y. Koizumi, Kogyo Kagaku Zasshi, 42, 810 (1939)

11) S. Okajima, K. Kurihara and K. Honma, $J$. Appl. Polym. Sci., 11, 1763 (1967)

12) S. Okajima and K. Kurihara, Sen-i Gakkaishi, 22, 206 (1966)

13) S. Okajima and K. Kurihara, Sen-i Gakkaishi, 22, $35(1966)$

14) R. J. Samuels, J. Polym. Sci., A-2, 6, 1101 (1968)

15) B. Wunderlich, Kolloid Z. Z. Polym., 231, 605 (1969)

16) H. G. Zachmann, Kolloid Z, Z. Polym., 206, 25 (1965); 216, 180 (1967)

17) H. G. Zachmann and P. Spelluci, Kolloid $Z$. Z. Polym., 213, 39 (1966)

18) E. Hellmuth and B. Wunderlich, J. Appl. Phys., 36, 3039 (1965)

高度に再延伸されたアイソタクチック

ポリプロピレンフィルムの構造特性

群馬大学工学部山本雄三, 出羽沢光人, 木下茂武

延伸一熱収樎によって作られた初期配向を古ったアイ ソタクチックポリプロピレン (iPP)フィルムが初期配向 軸 (first draw direction FDD) k対 $L \alpha(\alpha=0,30$, $\left.45,60^{\circ}\right)$ の角度で再延伸された。高度に再延伸された iPP フィルムは高度に再延伸軸 (second draw direction SDD）に再配向する。高度に再延伸することによ り，結晶配向拉よび非罩配向がそれぞれ $f_{\mathrm{c}}=0.992$ ， $f_{\mathrm{am}}=0.714$ めよう高い值をもつフィルムが得られた。 $T_{\mathrm{m}}$ の昇温速度依存性が険討され， superheatingは $f_{\mathrm{am}}$ に依存するととがわかった。昇温速度 $80^{\circ} \mathrm{C} / \mathrm{min}$ と $25^{\circ} \mathrm{C}$ $/ \min$ におる $T_{\mathrm{m}}$ の差はオリジナルフィルムと再延伸つ ィルムでは值線になる。

初期配问の履歴は高度に再延伸されたフィルムにも残 っておう，高温での熱収繀によりそれは圐れる。 